\title{
A GOOD TEACHER - MEDICAL STUDENTS VIEWS
}

\author{
DR. MAMATHA P SAMAGA ${ }^{1}$, DR. HEMALATHA NR ${ }^{2}$ \\ ${ }^{1}$ Assistant Professor, Dept of Microbiology ${ }^{2}$ Associate Professor, Dept of Physiology \\ MIMS, Mandya, Karnataka.
}

\begin{abstract}
Lectures have been the most common form of teaching and learning since ancient times. Success of lecturing sessions is inextricably linked with the excellent teaching process. The objective of our study was to find out medical students views about good teacher.The study instrument was a self-administered questionnaire. The study design was cross sectional. 86 pre-clinical M.B.B.S students volunteered to take part in the study. The questionnaire required the respondents to rate 15 parameters and responses were based on a 5 point Likertscale. Descriptive statistics was used for analysis of data and results were expressed as percentage. Among females, majority 30 (63.9\%) agreed for use of technology by teachers followed by 29(61.8\%) strongly agreeing for teacher summarizing topic at the end of the class, 28(59.7\%) for teacher to use simple language and $27(57.4 \%)$ for teacher to have good sense of humour. Among males, majority 36 (92.16\%) strongly agreed for teacher to have good sense of humour followed by 29(74.3\%) for teacher summarising topic at the end of the lecture, 27(69.1\%) for teacher to have command on subject. Students views should be considered and follow up studies should be carried out so that appropriate changes in teaching style can be made to justify the place of lecture as a mode of instruction in undergraduate medical education.
\end{abstract}

Key words : Good teacher, Lectures, medical students, medical education.

\section{INTRODUCTION}

Lectures have been the most common form of teaching and learning since ancient times [1]According to Bligh (2000) lecturing is "more or less the continuous exposition[s] by a speaker who wants his audience to learn something". Irrespective of these definitions, lectures are used to convey critical information to the listeners.[2]To maintain the credibility of the lecture as one of the important teaching tools due consideration should be given towards its organization and preparation and skillful presentation. Success of lecturing sessions is inextricably linked with the excellent teaching process. Medical educationists must review the place of lecture in relevance to the general objective of medical education that is to produce a physician capable of delivering appropriate health care.[3]. Good lecturers "light the match" - inspiring you to go and find out more. Bad lecturers try to "fill the bucket" and just load you with information.. John T Biehn [4] stated that "the field of medical education is somewhat unusual in that the great majority of medical teachers have had no formal training as teachers. Most of us begin teaching careers with the naïve hope that we might impart something of value through having a combination of clinical experience and interest in the welfare of the student (or postgraduate trainee)". Effective teaching in medicine is essential to produce good quality doctors. In the words of Ernest Leroy [5], "a poor surgeon hurts 1 person at a time but a poor teacher hurts 130". Feedback encourages discussion between tutors and learners so as to clearly define the goals to be achieved and to provide thought for food for the people involved in curriculum designing and development. This would help to make the medical education learner centred and friendly. It has been shown that credible feedback results could be used to modify teaching strategies according to the learning objectives and available resources. [6].

The objective of our study was to find out medical students views about good teacher by taking their feedback. This would help us to improve our lecturing styles to match the expectations of students and make it learner friendly.

\section{MATERIALS AND METHODS}

The study design was cross sectional. Data was gathered at_Mandya Institute of Medical Sciences (MIMS), Mandya from 86 pre-clinical M.B.B.S students who volunteered to take part in the study. Written informed consent from the participants was taken. Students who were at the end of their first M.B.B.S. were selected because their opinions would be based on one year experience of attending the lectures in a medical 
college. The study instrument was a self-administered questionnaire. It was prepared by discussion among the authors after a review of the existing literature. Statements describing desired qualities of an effective teacher were formulated based on previous research [7- $\underline{8}]$. The questionnaire comprised of 15 statements relating to qualities of good teacher. (Table 1) Each statement was discussed with the respondent to explain its meaning.. The questionnaire required the respondents to rate 15 parameters and responses were based on a 5 point Likertscale. i.e. $1=$ strongly disagree, $2=$ disagree, $3=$ neutral, $4=$ agree, $5=$ strongly agree. Anonymity was preserved during the data collection process. Descriptive statistics was used for analysis of data and results were expressed as percentage.

\section{RESULTS}

86 students participated in the study voluntarily, which included 47 (55\%) females and $39(45 \%)$ males. Among females, majority $30(63.9 \%)$ agreed for use of technology by teachers followed by $29(61.8 \%)$ strongly agreeing for teacher summarizing topic at the end of the class, 28(59.7\%) for teacher to use simple language and $27(57.4 \%)$ for teacher to have good sense of humour.

Table 1: Female students opinions to different parameters of good teacher

\begin{tabular}{|c|c|c|c|c|c|c|}
\hline $\begin{array}{l}\text { SI } \\
\text { no }\end{array}$ & Parameters & $\begin{array}{l}\text { Agree } \\
\mathrm{N}(\%)\end{array}$ & $\begin{array}{l}\text { Strongly } \\
\text { Agree } \\
\text { N(\%) }\end{array}$ & $\begin{array}{l}\text { Neither agree } \\
\text { Nor disagree } \\
\mathrm{N}(\%)\end{array}$ & $\begin{array}{l}\text { Disagree } \\
\mathrm{N}(\%)\end{array}$ & $\begin{array}{l}\text { Strongly } \\
\text { Disagree } \\
\mathrm{N}(\%)\end{array}$ \\
\hline 1 & Teacher announces topics $1 \mathrm{wk}$ prior to class & $18(38.3)$ & $25(53.3)$ & $3(6.4)$ & 0 & $1(2.1)$ \\
\hline 3 & $\begin{array}{l}\text { Teacher begins lecture class with questioning } \\
\text { related to topic }\end{array}$ & $8(17)$ & $21(44.7)$ & $7(14.9)$ & $7(14.9)$ & $4(8.5)$ \\
\hline 4 & Teacher introduces relevance of the topic & $26(55.4)$ & $19(40.5)$ & $2(4.3)$ & 0 & 0 \\
\hline 7 & Teacher uses simple language & $14(29.8)$ & $28(59.7)$ & $4(8.5)$ & $1(2.1)$ & 0 \\
\hline 8 & Handouts are given to students & $24(51.1)$ & $4(8.5)$ & $11(23.4)$ & $4(8.5)$ & $4(8.5)$ \\
\hline 9 & Textbooks allowed during lecture & $8(17)$ & $19(40.5)$ & $5(10.6)$ & $10(21.3)$ & $5(10.6$ \\
\hline 10 & Teacher summarizes topic at the end of lecture & $13(27.7)$ & $29(61.8)$ & $2(4.3)$ & 0 & $3(6.4)$ \\
\hline 14 & Teacher should be punctual & $18(38.3)$ & $23(48.9)$ & $6(12.8)$ & 0 & 0 \\
\hline 15 & Teacher should have good sense of humor & $18(38.3)$ & $27(57.4)$ & $2(4.3)$ & 0 & 0 \\
\hline
\end{tabular}

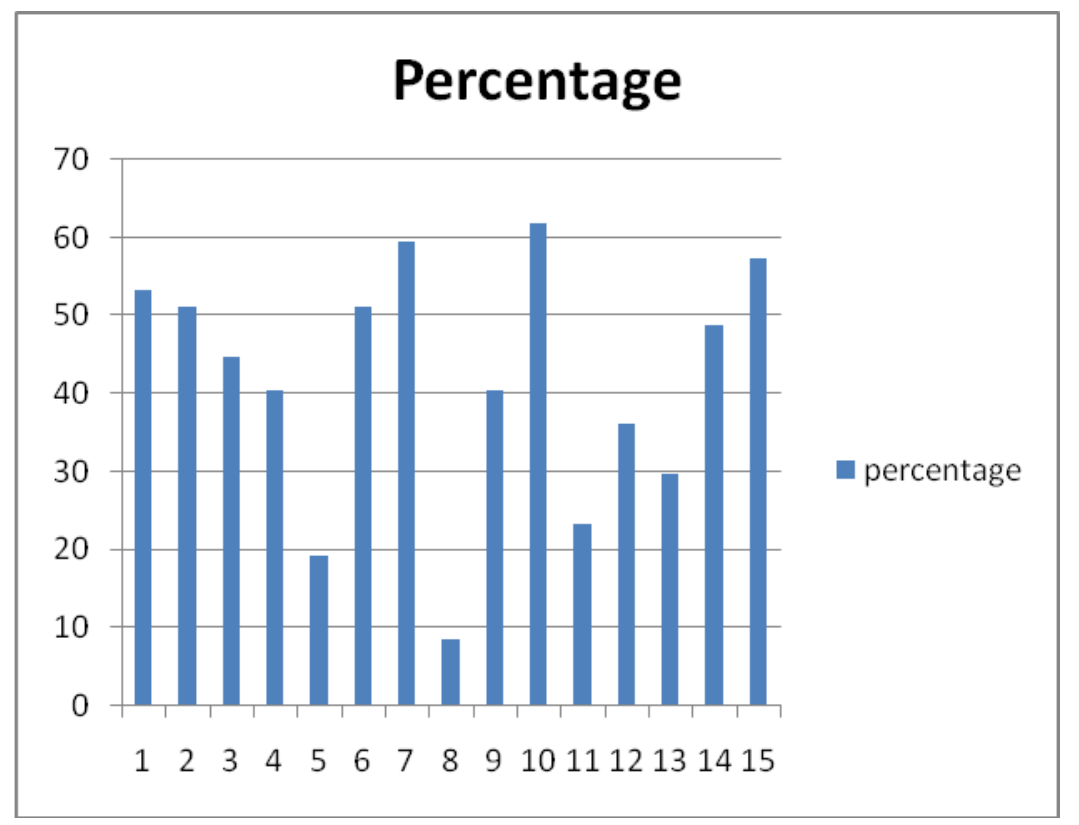

Fig 1: Percentage of females strongly agreeing for 15 parameters 
Among males, majority $36(92.16 \%)$ strongly agreed for teacher to have good sense of humour followed by $29(74.3 \%)$ for teacher summarising topic at the end of the lecture, 27(69.1\%) for teacher to have command on subject.

Table 2: Male students opinions to different parameters of good teacher

\begin{tabular}{|c|c|c|c|c|c|c|}
\hline $\begin{array}{l}\text { SI } \\
\text { no }\end{array}$ & Parameters & $\begin{array}{l}\text { Agree } \\
\mathrm{N}(\%)\end{array}$ & $\begin{array}{l}\text { Strongl } \\
\mathbf{y} \\
\text { Agree } \\
\mathbf{N}(\%)\end{array}$ & $\begin{array}{l}\text { Neither agree } \\
\text { Nor disagree } \\
\mathrm{N}(\%)\end{array}$ & $\begin{array}{l}\text { Disagree } \\
\mathrm{N}(\%)\end{array}$ & $\begin{array}{l}\text { Strongly } \\
\text { Disagree } \\
\mathrm{N}(\%)\end{array}$ \\
\hline 1 & Teacher announces topics $1 \mathrm{wk}$ prior to class & $11(28.2)$ & $25(64.1)$ & $1(2.6)$ & $2(5.1)$ & 0 \\
\hline 2 & Teacher enthusiastic about topic & $9(23)$ & $25(64.1)$ & $4(10.2)$ & 0 & $1(2.6)$ \\
\hline 3 & $\begin{array}{l}\text { Teacher begins lecture class with questioning } \\
\text { related to topic }\end{array}$ & $8(20.5)$ & $17(43.5)$ & $9(23)$ & $1(2.6)$ & $4(10.2)$ \\
\hline 4 & Teacher introduces relevance of the topic & $22(56.4)$ & $15(38.5)$ & $1(2.6)$ & $1(2.6)$ & 0 \\
\hline 5 & Teacher uses technology & $24(61.5)$ & $9(23)$ & $5(12.9)$ & 0 & $1(2.6)$ \\
\hline 6 & $\begin{array}{l}\text { There are breaks for discussions \& group } \\
\text { activity for students during lecture class }\end{array}$ & $6(15.3)$ & $25(64.1)$ & $3(7.7)$ & $1(2.6)$ & $4(10.2)$ \\
\hline 7 & Teacher uses simple language & $14(35.9)$ & $25(64.1)$ & 0 & 0 & 0 \\
\hline 8 & Handouts are given to students & $16(41)$ & $10(25.6)$ & $6(15.3)$ & $2(5.1)$ & $5(12.9)$ \\
\hline 9 & Textbooks allowed during lecture & $9(23)$ & $16(41)$ & $2(5.1)$ & $5(12.9)$ & $7(17.9)$ \\
\hline 10 & $\begin{array}{l}\text { Teacher summarizes topic at the end of } \\
\text { lecture }\end{array}$ & $8(20.5)$ & $29(74.3)$ & 0 & $2(5.1)$ & 0 \\
\hline 11 & $\begin{array}{l}\text { A regular formative assessment - as a part of } \\
\text { lecture is done by teacher }\end{array}$ & $10(25.6)$ & $15(38.5)$ & $8(20.5)$ & $1(2.6)$ & $5(12.9)$ \\
\hline 12 & Teacher should have command on subject & $10(25.6)$ & $27(69.1)$ & $2(5.1)$ & 0 & 0 \\
\hline 13 & Teacher should have good control on class & $12(30.8)$ & $23(58.9)$ & $2(5.1)$ & $1(2.6)$ & $1(2.6)$ \\
\hline 14 & Teacher should be punctual & $8(20.5)$ & $23(58.9)$ & $6(15.3)$ & $1(2.6)$ & $1(2.6)$ \\
\hline 15 & Teacher should have good sense of humor & $2(5.1)$ & $36(92.2)$ & $1(2.6)$ & 0 & 0 \\
\hline
\end{tabular}

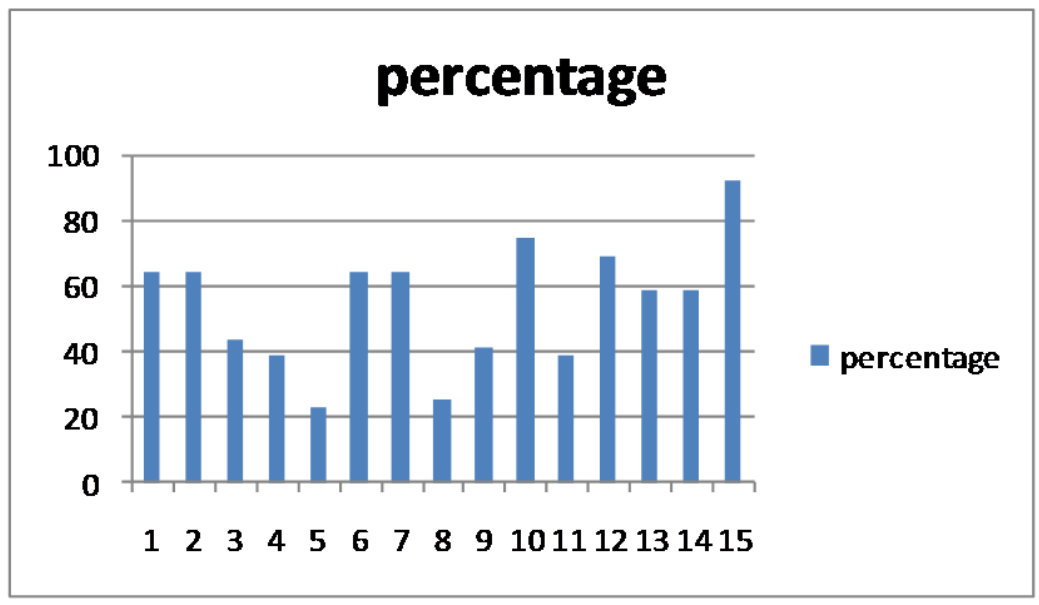

Fig 2: Percentage of males strongly agreeing for 15 parameters

\section{DISCUSSION}

Lectures remain the mainstay of medical education. They remain the easiest and most convenient way of imparting education to a large number of people even with limited resources.[9] A good teacher equips his/her students with a range of tools to be adept in this subject and to be able to see the relevance of it. In our study, we observed that maximum girls 30(63.9\%) agreed that teacher should use technology. Also, 29(61.8\%) and 28( 59.6\%), girls strongly agreed that teacher should summarize topic at the end of lecture and use simple language respectively. A good lecturer, from the student's view, needs to take advantage of using technologies to its full potential. Nowadays, most lecture classes are taken with PowerPoint presentations. The good teachers should take advantage of this, not only using it for text but also for diagrams, images and videos. Handouts are useful to avoid students from noting down everything the teacher is saying. They only need to add notes to the information that is already there in the hand outs.Being able to communicate ideas effectively in a simple way is important for a good teacher. 
Among boys, 36(92.2\%), 29(74.3\%) and 27(69.1\%) strongly agreed that teacher should have good sense of humour, teacher should summarize topic at the end of lecture and teacher should have good command over subject. Making students laugh should definitely be applied as an aid during the lecture. It takes some pressure off the students and acts as a minor break during what may be an unavoidably long session. Injecting a bit of humour into the mix always tends to lighten the tone, and laughter is supposedly said to act as a memory trigger, which could even enhance the learning of material by simple association (Nicholas, 3rd year student studying Information Technology). We observed a gender difference in strongly agreeing of the parameters as rated by maximum students.Majority of the females $(61.8 \%)$ strongly agreed that summarizing topic at the end of lecture was integral for a good lecture but majority of males(92.2\%) strongly agreed that teacher should have a good sense of humour.

One of important feature is facilitating interaction between teacher and students and amongst the students themselves. $25(64.1 \%$ ) boys in our study strongly agreed that there should be breaks for discussions \& group activity for students during lecture class. But, only 24(51.1\%) girls strongly agreed for this parameter. The boys felt that the breaks would refresh their minds whereas the girls felt that it would distract their attention from the lecture.

Good lecturers trigger enthusiasm and are often passionate about the subject they teach, even if that subject happens to be not that exciting. In our study, 25(64.1\%) boys \& 24(51.1\%) girls strongly agreed that teacher should be enthusiastic about the topic.Influencing factors for attending a lecture were identified as Friendly attitude of the teacher, Good control on class, punctuality, sense of humour, capacity of being internal examiner, and humane behaviour. It has been documented that personality traits of teachers greatly influence student's interest in lectures.[10]

Yilmaz A [11], who noted that a teacher should be "Enthusiastic, excited about teaching, dynamic, and motivates students to learn". Similarly in a study by Duvivier et al.[12] on perspectives of clinical skills lab teachers, enthusiasm emerged as the most important theme

In a study by Young and Shaw [13], effective communication skills emerged as one of the top seven qualities accounting for teaching effectiveness. Morrison et al. [14] in an online survey of residents and faculty using the Clinical Teaching Perception Inventory ${ }^{\circledR}$ (CTPI) included 28 descriptors of ideal clinical teachers and the top descriptors agreed between students and faculty were, "stimulating, encouraging, competent, communicates, and well-read." Knowledge of subject is a cognitive quality which can be developed and has been found to be an important characteristic in various studies across non-medical disciplines also [15-18]. According to Banner and Cannon[19], we as teachers, see success as a product of our level of academic development but we tend to overlook the importance of our own personality traits in determining our success or failure as teachers . Many researchers such as, Cruickshank, Jenkins and Metcalf[20] have highlighted that an effective teacher possesses characteristics such as sense of humor, warmth and enthusiasm

\section{CONCLUSION}

Students views should be considered and follow up studies should be carried out so that appropriate changes in teaching style can be made to justify the place of lecture as a mode of instruction in undergraduate medical education.By making careful changes in content, timing and mode of delivery and improving personality traits in teachers we can make the lectures more interesting to the students.

\section{REFERENCES}

[1]. Seth V, Upadhyaya P, Ahmad M, Moghe V. Powerpoint or chalk and talk: Perceptions of medical students versus dental students in a medical college in India. Adv Med Educ Pract 2010;1:11-6.

[2]. Bligh DA (2000). What's the use of lectures? (San Francisco: Jossey-Bass; pp. 4)

[3]. Sachdeva AK. Use of effective feedback to facilitate adult learning. J. Cancer, Educ., 1996;11:106-18.

[4]. Biehn JT: Characteristics of an effective medical teacher.Can Fam Physician 1976, 22:1325-1326.

[5] Boyer EL: Medical education.Web site. [http://medicaleducation.wetpaint.com/ ]

[6]. Nnodim JO, Ohanaka EC, Osuji CU. A follow up comparative study of two modes of learning human anatomy. Clin. Anat., 1996:9:252-62.

[7]. Boendermaker PM, Schuling J, Meyboom-de Jong B, Zwierstra RP, Metz JCM: What are the characteristics of the competent general practitioner trainer? A qualitative study examining the characteristics of the competent GP-trainer. Fam Pract 2000, 17(6):547-553.

[8]. Buchel TL, Edwards FD: Characteristics of effective clinical teachers. FamMed 2005, 37(1):30- 35

[9]. Stuart J, Rutherford RJD. Medical student concentration during lectures. Lancet 1978;2(8088):514-6.

[10]. Bollemier SG, Wenger PJ, Fornaish AB. Impact of online lecture-capture on student outcomes in a therapeutic course. Am $J$ Pharma Educ 2010;74(7):1-5. 
[11]. Yilmaz A: Quality problem in teaching profession: Qualities teacher candidates feel to be required of teachers.Educ Res Rev 2011, 6(14):812-823

[12]. Duvivier RJ, Van Dalen J, Van der Vleuten CP, Scherpbier AJ: Teacher perceptions of desired qualities, competencies and strategies for clinical skills teachers. Med Teach 2009, 31(7):634-41.

[13]. Young S, Shaw DG: Profiles of effective college and university teachers.J Higher Educ 1999, 70(6):670-686.

[14]. Morrison EH, Hitchcock MA, Harthill M, Boker JR, Masunaga H: The on-line clinical teaching perception inventory: A" snapshot "of medical teachers. Fam Med 2005, 37(1):48-53.

[15]. Ballantyne J: Integration, contextualization and continuity: three themes for the development of effective music teacher education programmes. Int j Music Educ 2007, 25(2):119-136.

[16]. Bain K: What the best college teachers do. (Cambridge, MA: Harvard University Press; 2004).

[17]. Levy JB: As a last resort, ask the students: what they say makes someone an effective law teacher. Maine Law Rev 2006, 58(1):50-98.

[18]. Kelly C: Student's perceptions of effective clinical teaching revisited.Nurse Educ Today 2007, 27(8):885-892.

[19]. Banner JM, Cannon HC: The elements of teaching (Connecticut; Yale University Press; 1997)

[20]. Cruickshank DR, Jenkins DB, Metcalf KK: The act of teaching ( New York; McGraw-Hill; 2003). 